\title{
Using WebGIS Platforms and Inquiry-based Activities to Teach about World Political Map and World Population
}

\author{
Stela CSACHOVÁ1 \\ Pavol Jozef Šafárik University, Košice, SLOVAKIA
}

IPhD. Pavol Jozef Šafárik University, Institute of Geography, Košice, Slovakia. stela.csachova [at] upjs.sk. ORCID: 0000-0003-3980-5650

\section{Abstract}

In Slovakia, a national project IT Academy - the education for the 21st century - was launched to promote student interest in science, mathematics and informatics across secondary education; and to also prepare students for the digital age. Geography education has an opportunity to undergo a process of reconceptualization and change in response to an increased use of technology. Recent trends in geography education which are occurring as a result of technological developments have resulted in the map, a primary tool of a geographer, becoming substituted by digital technologies such as Geographic Information Systems (GIS). However, digital advancements have not been reflected in the teaching and learning of geography. Therefore, based on such an assumption, the aim of the current study is to encourage Geography students to acquire knowledge and develop skills through the purposeful use and implementation of geospatial technologies. The paper presents learning activities about World Political Map and World Population for secondary school students who are studying Geography, which are designed to make Geography lessons more inquiry-based with real-life application. The activities were piloted and evaluated by Geography teachers all over Slovakia. In conclusion, the statements from teachers confirm the project is relevant for gradual reform of geography education in our country.

\section{Keywords}

Geography Education, IT Academy, Web GIS Platform, World Political Map, World Population 
Questions as "Where?" and "Why there?" become fundamental for understanding the $21^{\text {st }}$ century world. These questions are also the essence of geography, a discipline that bridges natural and social sciences. Geography, as stated in the International Charter on Geography Education (2016), explores spatial variability; appreciates how places and landscapes are formed; seeks to understand how people and environments interact together with how the Earth's diverse mosaic of cultures and societies are interconnected; and investigates the consequences that arise from everyday spatial decisions (p. 4). A geographer's primary tool is a map and in recent years, this tool has been advanced by digital technologies such as Geographic Information Systems (GIS). GIS-based geography lessons support inquiry by allowing students to (i) obtain geographical data from multiple sources; (ii) analyze and present geographical data and information in the forms of maps, images, tables, charts; (iii) answer the inquiry questions and draw conclusions (Demirci, 2015, p. 142). Students' attitudes are positive towards lessons which incorporate the use of GIS (Artvinli, 2010, p. 1277).

In Slovakia, a national project IT Academy - the education for the $21^{\text {st }}$ century was launched to promote student interest in science subjects (biology, chemistry, physics, and geography), mathematics and informatics in secondary education. The project was also designed to prepare students for the needs of the digital age (www.itakademia.sk). IT Academy is a networking platform operated by the Centre of Scientific and Technical Information under the Ministry of Education to connect education professionals, university lecturers, secondary teachers and students. The priority is to introduce inquiry-based lessons which are supported by the use of digital technologies with the aim of developing a more active process towards the acquisition of knowledge and skills. The project occurs nation-wide and influences hundreds of teachers and thousands of students across Slovakia. As a result, the project has given geography a feasible chance of undergoing reconceptualization and change in response to implementing the latest trends to geography education.

The aim of this paper is to present a path of reconceptualization and change to geography education by using the frames of the IT Academy project to present the outputs from the current study: a series of learning activities about World Political Map and World Population which are focused on geographical inquiry using Web GIS platforms.

\section{Background}

In Slovakia, geography is a stand-alone curricular subject where instruction occurs across lower and higher secondary education. The educational standards for geography are included in a State Educational Program (National Curriculum) together with other school subjects, organized into educational areas. The educational standards are defined by performance and content as a minimal level of knowledge and skills students have to achieve. The State Educational Program also appoints minimal number of teaching periods for each subject. The lower secondary education (ISCED2) accounts for five grades - from the fifth to the ninth. For Geography it is two lessons per week in the fifth grade and one lesson per week in each consecutive grade. Higher secondary education (ISCED3) consists of four grades and appoints four lessons of Geography divided into these four grades; most commonly it is one lesson per 
week in the first grade, two per week in the second grade and one in the third grade. Regarding content knowledge, school geography in Slovakia is overwhelmingly oriented towards regions of the world, their physical and human geographical features, which are then compared with the situation of a home country. The goals of geography education at higher secondary education (according to the State Educational Program, 2015, p. 3) state that students will:

- Search, compare and assess geographical information about landscape from different information resources;

- Present the information about landscape in visual graphics (maps, graphs, tables, schemes, diagrams, photographs, etc.);

- Interpret maps in digital (3d) and printed (2d) versions;

- Reason for different physical conditions for life on earth and their impact to society;

- Take a stand about key global problems and prospective solutions; and

- Understand the complexity of landscape, and the interrelationships of physical and socio-economic systems.

Geography education in Slovakia is under the critique of university educators (Karolčík et al., 2015; Csachová, 2018) as well as education analysts (Rehúš, 2018). Much of the debate is concerned with the long-lasting static system of geography teaching (Tolmáči \& Karolčík, 2017, p. 34) and rote description of world regions and states. Since transmission remains the most widely used method of instruction, the process of reconceptualization and change to geography education should encourage a more active approach towards learning through developing inquiry-based lessons which are supported by the use of digital technologies (Kireš et al., 2019). In response to such a situation, Škodová \& Trniková (2019) envisaged an inductive instruction method. Most of the inquiry-based resources for teachers are associated with themes of physical geography such as the lithosphere, atmosphere, hydrosphere, pedosphere (Karolčík \& Čipková, 2015; Čipková, Balážová \& Karolčík, 2017; Škodová \& Schubertová, 2018; Karvánková 2015; Karvánková et al., 2017). Less attention is devoted to inquiry-based activities for human geography focused content (Mládek et al., 2017) so that is why this paper aim to address a topic related to human geography.

Teaching geography with the support of GIS is an internationally rich topic of research and discussions; and the literature advocates for the use of geospatial technology in geography education (Demirci, 2015, p. 146). In Slovakia, there is only one survey about how GIS is practiced at schools from teachers' perspective (Karolčík, Čipková, Mázorová, 2016). For the successful implementation of GIS in geography education, not only should the school should be fully equipped with the appropriate technologies, the school management and professional teachers should also be convinced about its use (Král \& Řezníčková, 2013, p. 278). The situation around GIS implementation at school varies throughout the world and is given in a country-profiled analysis by Milson et al. (2012). Newly established geospatial technologies with geography education are well presented in Solari et al. (eds.) (2015). Since the use of GIS is only marginally integrated into Slovakia's geography curriculum, geospatial technologies are being quite slowly introduced into geography lessons. Amongst the most frequent answers about why geospatial technologies are being slowly 
introduced into the teaching and learning of geography, it is due to insufficient hardware and software equipment together with the fact that most teachers have not been trained to use geospatial technologies. There are also different levels of integration of GIS into geography education. Van der Schee et al. (2015, p. 19) says developing meaningful learning units that help to train students' higher order thinking skills is required to make optimal use of geospatial technologies.

\section{Methodology}

The IT Academy project commenced in 2016 and will be finished in 2020. Each subject was considered by a team of experts, who during the first year of the project were involved in creating sixty innovative model lessons for their due subject. The expert team for Geography who included university lecturers from four Slovak universities, plus primary and secondary school teachers worked out sixty innovative model lessons for higher secondary education programs. A model lesson:

- involves description of whole (mostly 45-minute) lesson;

- consists of a title page, a lesson plan, materials for teachers, and handouts for students;

- is piloted by the teachers who are also the evaluators participating in the project;

- is evaluated by the teacher;

- is revised by the member of expert team;

- reiterates the testing process by teachers; and

- is finalized by the member of expert team.

Teachers evaluating the model lessons use the project portal for writing down their comments. The evaluation questionnaire comprising 12 questions addresses linkages to the subject curriculum, timing, learning objectives - acquiring knowledge and skills, problem-solving, instructional methods and forms, inquirybased learning, teaching aids and resources, forms of assessment, quality of worksheets, and an overall recommendation. Teachers expressed their attitudes mainly qualitatively. The evaluation questionnaire is the same for all subjects participating in the project.

As far as the position of geography in this project is concerned, a unique opportunity is provided to refine geography education by implementing content and methodical innovations, primarily through active learning, inquiry and the use of geospatial technologies. According to the team of experts, innovations in Slovakia for geography education are substantially associated with:

- content and methodical shifts towards enhancing spatial thinking skills;

- inquiry-based activities with real-life $21^{\text {st }}$ century issues of different scales;

- effective use of accessible geospatial technologies;

- work with geographical data - data collection, processing, visualization, interpretation and presentation;

- critical thinking of the world political situation and world global problems; and

- enhancing communication, collaboration and creativity.

In the next part of the paper, the six in-class learning activities are presented [Table 1]. The activities state the learning outcomes, dominant cognitive levels, 
dominant modes of spatial thinking, some cross-subject connections, and approximate timeframe for each lesson. The topic of World Political Maps and World Population is usually instructed in the second grade of higher secondary education. Activities are designed to correspond with the State Educational Program in Slovakia; however, the activities also extend and enrich learning through the introduction of new content knowledge and geographical skills. The activities also aim to develop various modes of spatial thinking (Gersmehl, 2014, p. 156) and reflect Bloom's taxonomy. All activities, except for one, include the use of computers (or notebooks), freely accessible Web GIS platforms, and Google maps, only the Google Earth Engine needs to log in. Tools to support formative assessment were used because formative assessment approaches help to improve levels of student achievement, enhance the social climate of the classroom and help the student to accept that assessment is an integral part of life Orosová et al. (2019, p. 19). Teachers are encouraged to question, analyze and discuss the students' works, mostly in response to the practical activities and worksheets.

Table 1

List of Learning Activities, the Number of Evaluators and Students Participating in the Learning Activity

\begin{tabular}{lll}
\hline Learning activities & Number of evaluators* & $\begin{array}{l}\text { Number of } \\
\text { students* }\end{array}$ \\
\hline $\begin{array}{l}\text { State, its Territory and Borders } \\
\text { Find the ideal location of the }\end{array}$ & 29 & 614 \\
$\begin{array}{l}\text { capital } \\
\begin{array}{l}\text { World in demographic } \\
\text { statistics }\end{array}\end{array}$ & 60 & 167 \\
\hline $\begin{array}{l}\text { What does the age pyramid } \\
\text { reveal? }\end{array}$ & 32 & 610 \\
\hline $\begin{array}{l}\text { Population prognosis } \\
\text { Demographical profiles of } \\
\text { selected states }\end{array}$ & 31 & 662 \\
\hline
\end{tabular}

* Data to January 2020

\section{Findings}

Teaching and learning about world population and political geography with Web GIS tools is important because "it brings problem solving, critical thinking, and collaboration to the classroom" (Kerski 2019a, p. 126) Here, we present learning activities conducted for geography lessons within the IT Academy project. 
Csachová, Stela. (2020) / Using webGIS platforms and inquiry-based activities to teach about ...

State, its Territory and Borders

\begin{tabular}{|c|c|}
\hline Acquiring knowledge & $\begin{array}{l}\text { Define a state } \\
\text { - Estimate the current number of states in the world } \\
\text { and explain why the number can be different in } \\
\text { various information resources } \\
\text { - Give the largest states in terms of area and } \\
\text { population Explain the reasons why and how } \\
\text { states have been established } \\
\text { - Understand a state morphology and specific } \\
\text { territories (enclave, exclave, corridor) }\end{array}$ \\
\hline Acquiring skills & - Work with geographical atlas, Web GIS tool \\
\hline $\begin{array}{l}\text { Dominant cognitive } \\
\text { levels }\end{array}$ & $\begin{array}{l}\text { - Remember } \\
\text { - Understand } \\
\text { - Apply }\end{array}$ \\
\hline $\begin{array}{l}\text { Dominant modes of } \\
\text { spatial thinking }\end{array}$ & $\begin{array}{l}\text { - Delimiting a region } \\
\text { - Comparison }\end{array}$ \\
\hline Cross-subject relations & - Civics, History \\
\hline Approximate time & - 45 minutes \\
\hline Assessment & $\begin{array}{l}\text { - Using worksheet, students suggest suitable } \\
\text { geographical questions for study, provide } \\
\text { relevant examples and communicate their } \\
\text { findings using appropriate vocabulary. }\end{array}$ \\
\hline
\end{tabular}

One of the things that makes political geography fascinating is the many unique, unusual cases, furthermore, the political boundaries can be taught using particular Web GIS tools (Kerski, 2019b, p. 180). With this belief, the suggested activity deals with a state as a fundamental political region on the world political map. The knowledge goals are to (i) define a state and its main attributes (territory, population, power, sovereignty); (ii) to explain how and why states have been established; and (iii) to reason why the number of states can vary in different resources. States can be compared by myriads of criteria, yet area and population are the most common criteria used. Students also discuss the morphology of a state, and the advantages and disadvantages of a particular state shape.

At the beginning of the lesson, students using their book atlases are asked to sketch the territory of five states - Namibia, Poland, Vietnam, South Africa and Angola. 


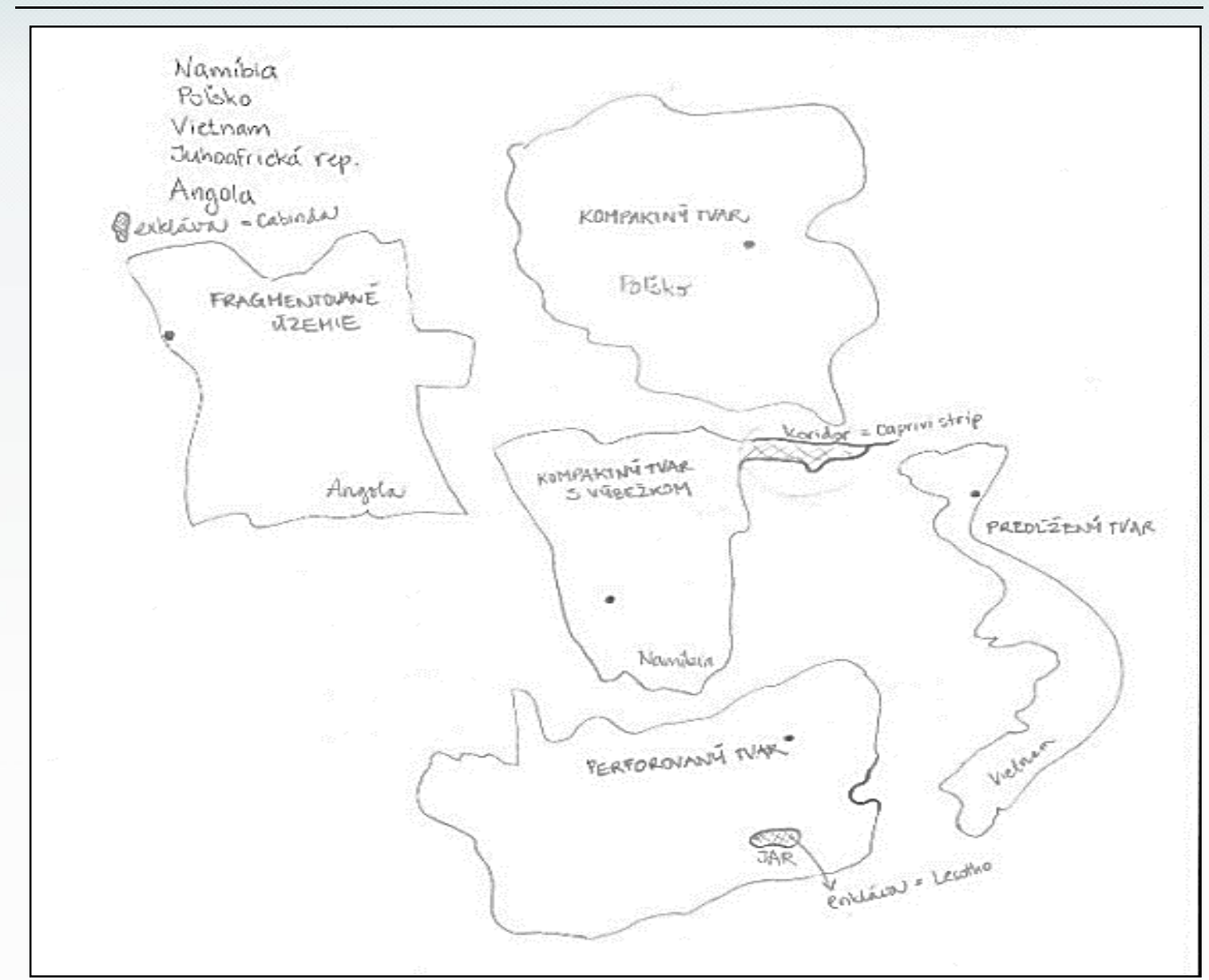

Figure 1. Student's product in the activity State, its Territory and Borders

Figure 1. The selection of states is deliberate, since each of them has a specific morphological feature. Students understand the difference between the shape of each states' territory. Student can also outline the advantages and disadvantages of all of the shapes and focus on the enclaves, exclaves, and corridors as appropriate. Students may leave unnoticed the Angola's exclave Cabinda, Namibia's corridor Caprivi Strip or South Africa's enclave Lesotho. In such a sketch, students become aware that the size of states cannot be compared. For comparing the size of the states, students are recommended to use the Web GIS tool www.overlapmaps.com or www.thetrusize.com. Teachers expressed overall satisfaction with the activity:

Students were motivated to work; they liked the activity. They worked with the atlas, Web GIS tool, and had time for discussion. Teachers also identified expected inaccuracies with student work, for example some students forgot to draw the corridor. Some had problem to distinguish between exclave and enclave, but using the examples, they understood. Teachers noted the activity also aroused discussions amongst students: there were fruitful discussions, for example, about whether or not a state can occupy more morphological categories.

\section{Find the Ideal Location of the Capital}

The second activity follows on the morphology of the state territory and the position of the capital within it. The teacher explains the role of the capital, its 
Csachová, Stela. (2020) / Using webGIS platforms and inquiry-based activities to teach about ...

location (in absolute and relative terms) and reasons why some relocations of capital cities occurred. An ideal spatial state shape is considered to be circular with the capital in the center. The aim of the activity is to find the ideal location of the capital city of the selected states by constructing the centroids. For this purpose, a Google account in Google Earth Engine is required.

\begin{tabular}{|c|c|}
\hline Acquiring knowledge & $\begin{array}{l}\text { Explain the capital and its functions } \\
\text { Give examples of states relocating their capitals and } \\
\text { reason why they are relocated } \\
\text { Give examples of the usability of centroids in } \\
\text { geographical research }\end{array}$ \\
\hline Acquiring skills & Geospatial skills \\
\hline $\begin{array}{l}\text { Dominant cognitive } \\
\text { levels }\end{array}$ & Apply \\
\hline $\begin{array}{l}\text { Dominant modes of } \\
\text { spatial thinking }\end{array}$ & Delimiting a region \\
\hline Cross-subject relations & Informatics \\
\hline Approximate time & 45 minutes \\
\hline Assessment & $\begin{array}{l}\text { Students use a range of geographical and IT skills to } \\
\text { investigate the theme, and present their findings } \\
\text { orally and graphically. }\end{array}$ \\
\hline
\end{tabular}

In the middle of the lesson, students are introduced to constructing centroids through the use Google Earth Engine. Programming procedures and several scripts are presented by the teacher. Students are asked to find a country in the world that has an unfavorable, peripheral location of the capital (for example, Slovakia, Uzbekistan, or the United States of America). Then, following teacher's instructions on scripting, students delimit a polygon and the program computes a centroid. Students look into the digital atlas to discover whether there are one or more cities near the centroid and whether one or more of these cities have the ideal location for being the capital city. Students present their findings and compare them with the location of real capital cities. Figure 2 illustrates another task: "Where would the ideal location be for a capital city of the United States of Europe, if it existed?" The program computed a centroid of a polygon. Student applied the procedure, analyzed and commented on their findings. 


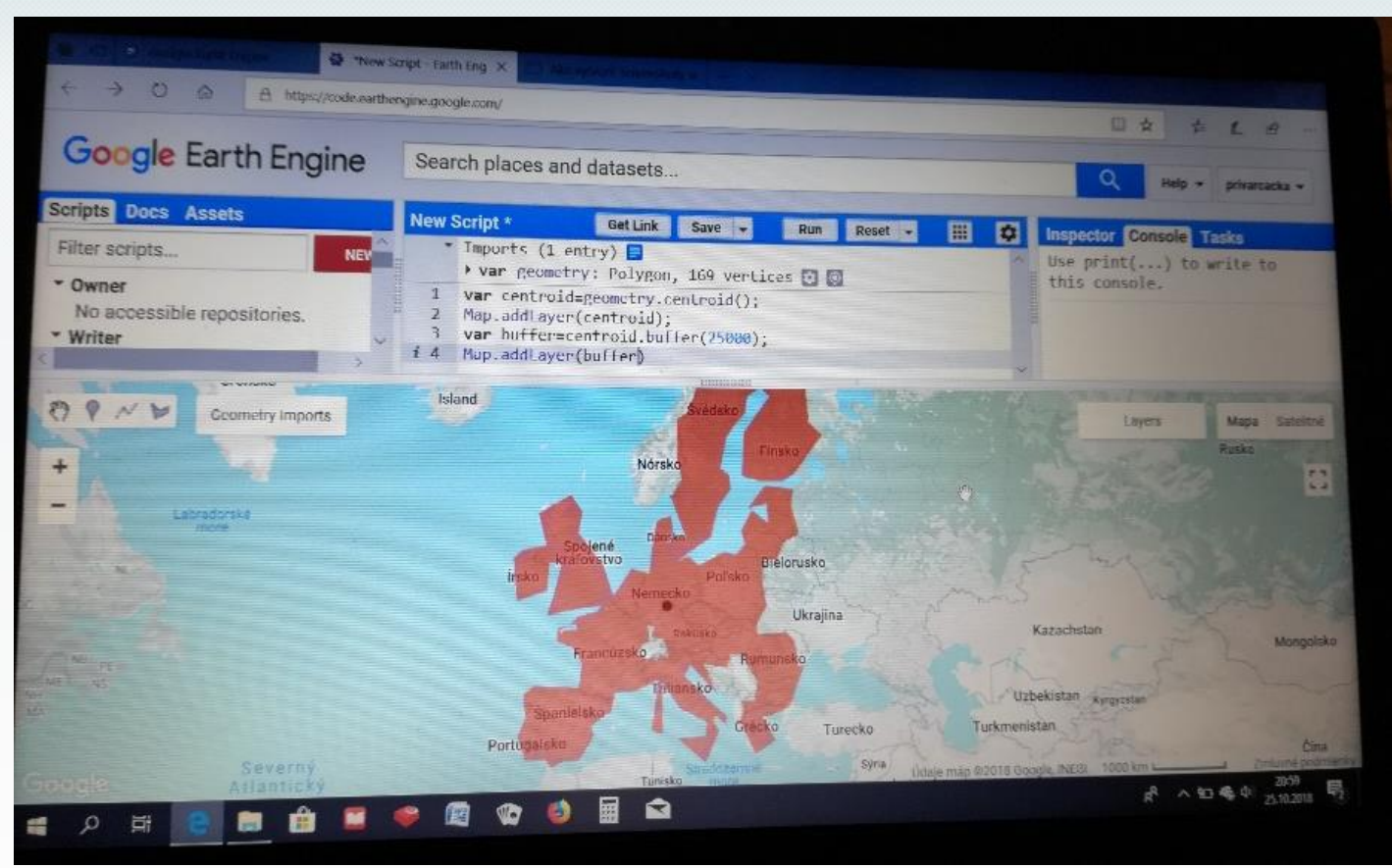

Figure 2. Student's product in the activity Find the Ideal Location of the Capital

Teachers' opinions on this activity were positive, and they appreciated the cross-subject relation with informatics:

The activity develops programming skills; and also, the potential for inquiry to occur to find a centroid of a polygon using Google Earth Engine is definitely an inquiry-based learning activity. The lesson created space for argumentation, analysis, causality, and presentation. A teacher identified the activity as being helpful for promoting student choice in learning, for example a student wanted to work with Gibraltar or Singapore.

\section{World in Demographic Statistics}

The third activity is devoted to demographic indicators in statistical databases of the world population. The aim is to provide students with credible sources of information about world population. At the beginning of the lesson, students define and understand most commonly used demographic indicators and observe 'population watch' on the Internet. They work with World Population Prospects a freely downloadable publication from the United Nations (UN WPP, 2017). Students collect, analyze and compare demographic data, and focus on extreme values of total fertility rate, life expectancy at birth, and under-five mortality rate throughout the world. Then students continue with constructing a demographic profile of a selected state using a Web GIS platform. 
Csachová, Stela. (2020) / Using webGIS platforms and inquiry-based activities to teach about ...

Acquiring knowledge Define terms population change, life expectancy, total fertility rate, under-five mortality, age pyramid Interpret the demographic indicators presented in tables, on maps

Analyze demography of a selected state and compare it with other states and the world

Generalize the facts

Acquiring skills

Dominant cognitive levels Explore geographic information and present it

Understand

Analysis

Evaluation

Dominant modes of Comparison

spatial thinking

Influence

Analogue

Associations

Cross-subject relations English, Mathematics

Approximate time 45 minutes

Assessment Using worksheet, students use sources to respond to a range of geographical questions.

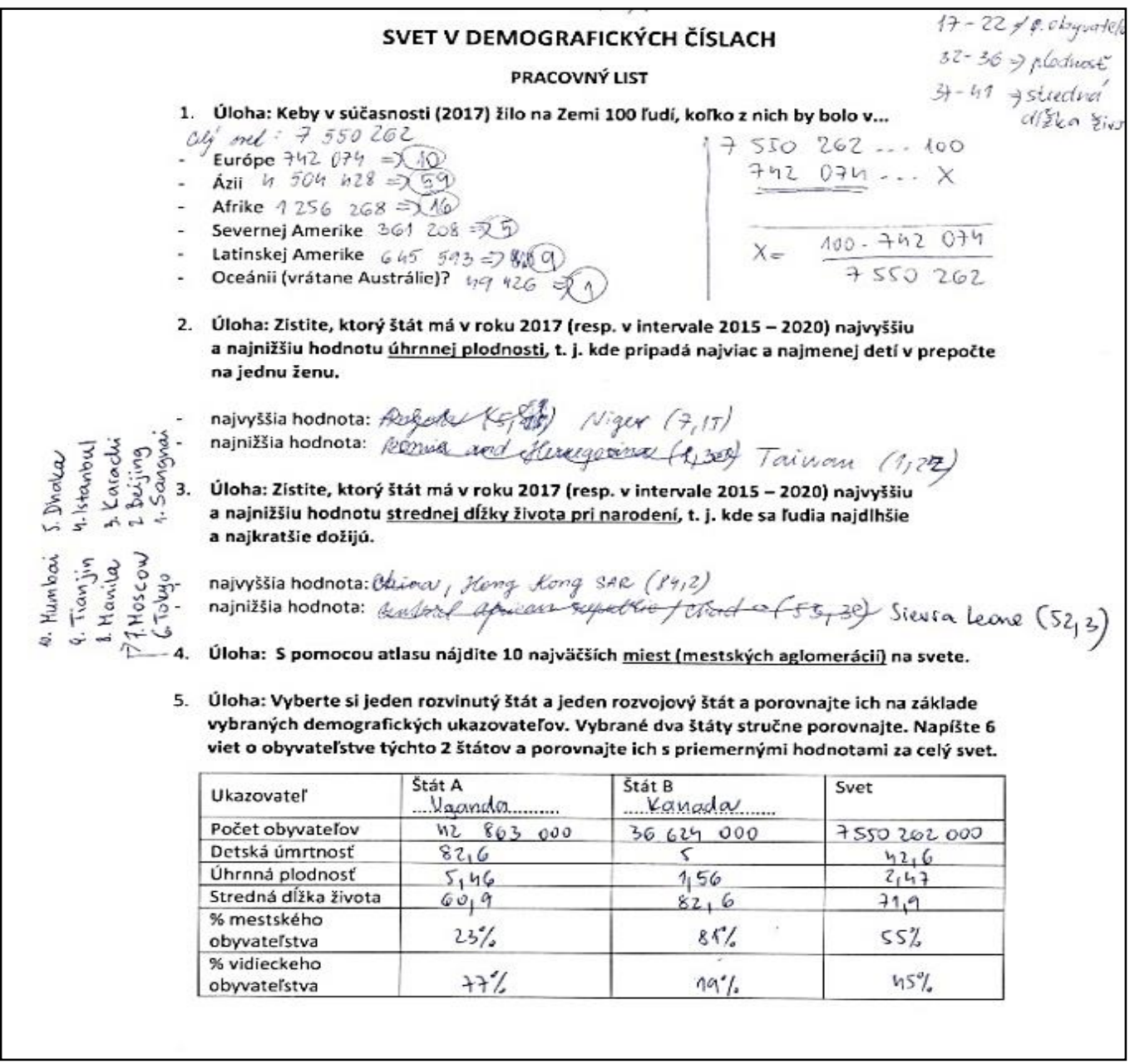

Figure 3. Student's product in the activity World in Demographic Statistics 
The handout is written in the Slovak language so the five exercises are translated below:

1. Estimate the numbers - if there were hundred people in the world, how many of them would live in Europe, Asia, Africa, North America, South America and Oceania (including Australia)?

2. Find states which in 2017 (or interval 2015 - 2020) had the highest and lowest value of total fertility rate and try to explain why it was so.

3. Find states which in 2017 (or interval 2015 - 2020) had the highest and lowest value of life expectancy at birth and try to explain why it was so.

4. Find ten largest city agglomerations in the world and comment on their localization.

5. Select two states (one developed and one developing) and compare them in terms of basic demographic indicators. Write a short comparative report.

After having this lesson taught, teachers reflected:

Teacher acknowledged the activity as being very relevant for the student learning in Geography. Students were overwhelmed by having seen population watch, it stimulated them to have more questions and considerations. However, teacher also identified students' problems with calculating the percentages.

\section{What Does the Age Pyramid Reveal?}

This activity is devoted to the age and gender structure of population, which is visualized by population pyramid. The shape of an age pyramid reveals the condition of the state's population. Generally, we distinguish progressive, regressive and stationary types of population pyramids. Some states' population pyramids have a specific shape which catches students' curiosity. The question about 'Why?' emerges from the students, for example why is there a "narrow base, wide base, bulges, or indents" in certain population pyramids. Students are asked to construct a population pyramid using (i.) metadata released by the United Nations World Population Prospects in .xls format and (ii.) a freely downloadable population pyramid template. Students select and analyze data, construct a population pyramid, interpret its shape, and compare it with other students' products.

\begin{tabular}{ll}
\hline Acquiring knowledge & $\begin{array}{l}\text { Define and describe the main types of age pyramids } \\
\text { Give examples of regions and states with basic types } \\
\text { of age pyramids } \\
\text { Explore specific shapes of age pyramids } \\
\text { Generalizing the facts }\end{array}$ \\
\hline Acquiring skills & $\begin{array}{l}\text { Search, collect geographical data } \\
\text { Communication skills }\end{array}$ \\
\hline Dominant cognitive & $\begin{array}{l}\text { Understand } \\
\text { levels }\end{array}$ \\
& $\begin{array}{l}\text { Apply } \\
\text { Analysis } \\
\text { Evaluation }\end{array}$ \\
Dominant modes of & Comparison \\
spatial thinking & Associations \\
Pattern
\end{tabular}


Csachová, Stela. (2020) / Using webGIS platforms and inquiry-based activities to teach about ...

\begin{tabular}{ll}
\hline Cross-subject relations & Informatics, Mathematics \\
\hline Approximate time & 45 minutes \\
\hline Assessment & $\begin{array}{l}\text { Students make effective use of their knowledge and } \\
\text { skills in carrying out the investigation, and present } \\
\text { their findings orally and graphically. }\end{array}$ \\
\hline
\end{tabular}

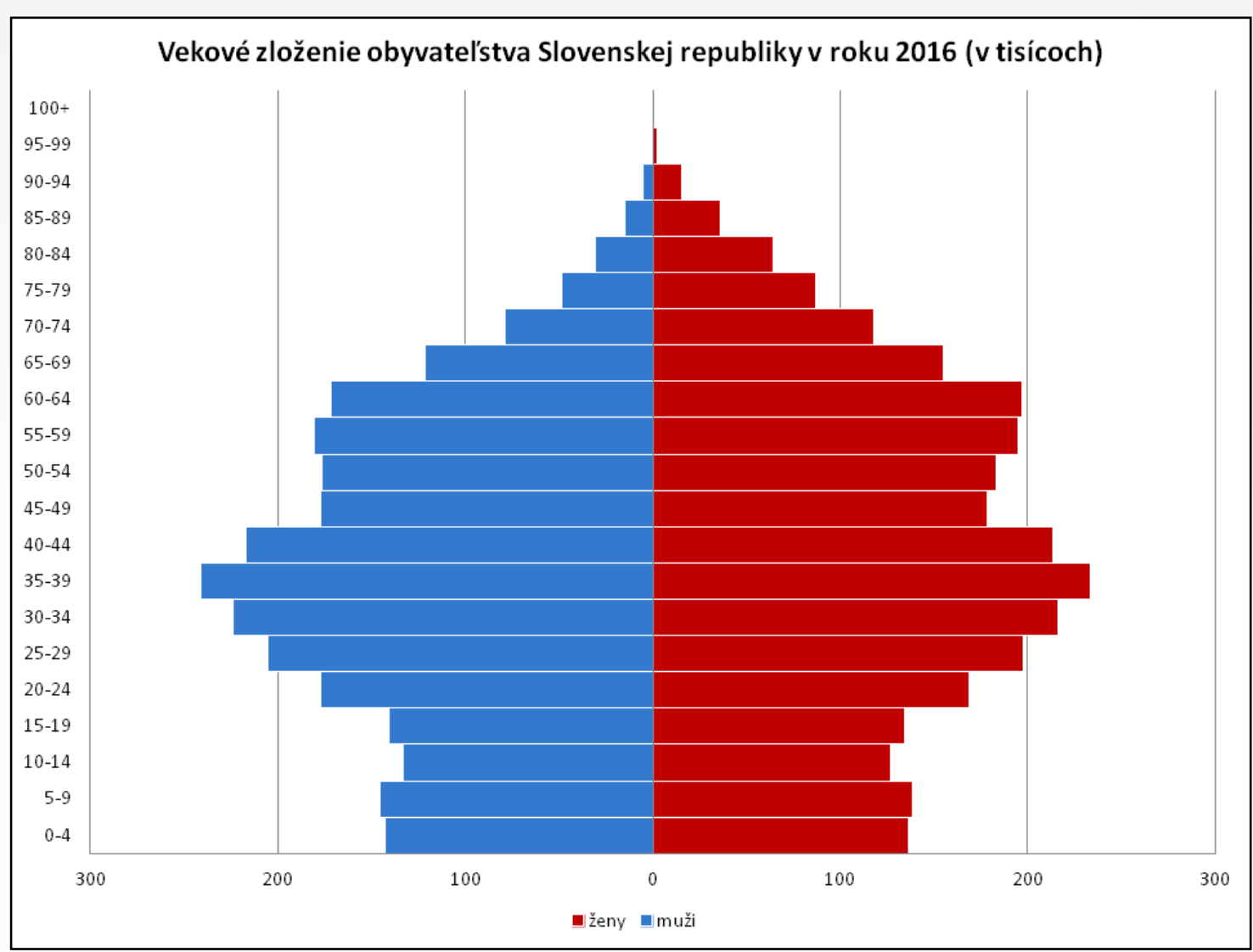

Figure 4. Student's product in the activity what does the age pyramid reveal

Figure 4 shows population pyramid of Slovakia in 2016 constructed by a student. In teachers' statements:

The activity got students to think and to associate, it nicely integrated theoretical knowledge and practical skills; and students appreciated to make up their own product. One teacher modified the activity to the learning needs of the students and added one more task to find at least two - three states with the very similar shape of age pyramid and reason why it was so.

\section{Population Prognosis}

This activity deals with population prognoses. At the beginning of the lesson, students are briefly instructed about how population prognoses are projected and they are introduced to a rich vocabulary of "movement language" by their teacher. This activity has a cross-subject relation with the Slovak language. Students work with the online tool www.populationpyramid.net and handouts. To practice describing different curves of population development, students are asked to look for the three states which show different population prognoses. Based on data and information in the graphs, students write down short 
descriptions of the population prognosis using proper vocabulary and stylistics [Figure 5].

\begin{tabular}{|c|c|}
\hline Acquiring knowledge & $\begin{array}{l}\text { Understand how population prognoses are } \\
\text { projected } \\
\text { Express the projection of population using a } \\
\text { vocabulary of "movement language" }\end{array}$ \\
\hline Acquiring skills & Reading and writing skills \\
\hline $\begin{array}{l}\text { Dominant cognitive } \\
\text { levels }\end{array}$ & $\begin{array}{l}\text { Understand } \\
\text { Apply }\end{array}$ \\
\hline $\begin{array}{l}\text { Dominant modes of } \\
\text { spatial thinking }\end{array}$ & $\begin{array}{l}\text { Comparison } \\
\text { Change }\end{array}$ \\
\hline Cross-subject relations & Slovak language \\
\hline Approximate time & 45 minutes \\
\hline Assessment & $\begin{array}{l}\text { Using worksheet, students use sources to respond to } \\
\text { a range of geographical questions, using } \\
\text { appropriate vocabulary and language of } \\
\text { geography. }\end{array}$ \\
\hline
\end{tabular}

The literal translation of Figure 5 is included below to clarify the meaning:

- Canada - Since 1950 the population is moderately increasing. The population around 2100 will approach to 50 million.

- Slovakia - Since 1950 the increase of population was continuous. In 2000 there was stagnation which lasts up to 2025. Since then, the moderate decrease is expected. The peak was during stagnation period with 5,5 million.

- Hungary - Hungary is a decreasing country in number of populations. It achieved its peak in 1980. Since then, the population has been decreasing.

In this activity, grammar inaccuracies and stylistics may occur in their interpretations. Teachers appreciated students' work from the lesson:

The lesson was vital, the students were motivated. The activity gets students to practice their writing skills and making associations. One of teachers appreciated the transferability of skills gained from this activity. Another teacher acknowledged this activity should be included in to their school curriculum. 


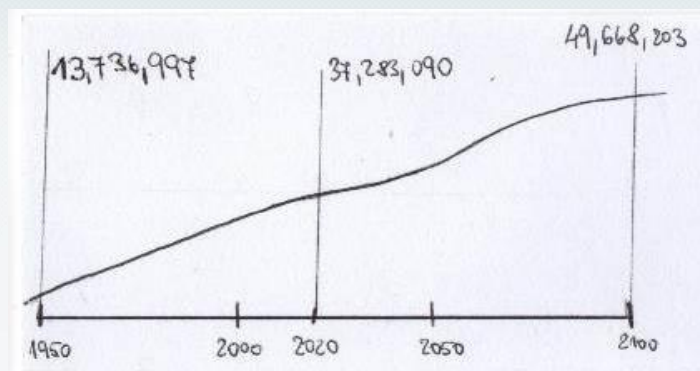

KANADA

Od rolew 1950 poied obyvatetor $N$ Kanade plymule mierme stifa. Poúl obyrabelor by $\mathrm{ra}$ mal oholo nokw 2100 priblikit h 50 miliónom.

\section{SLOVENSKO}

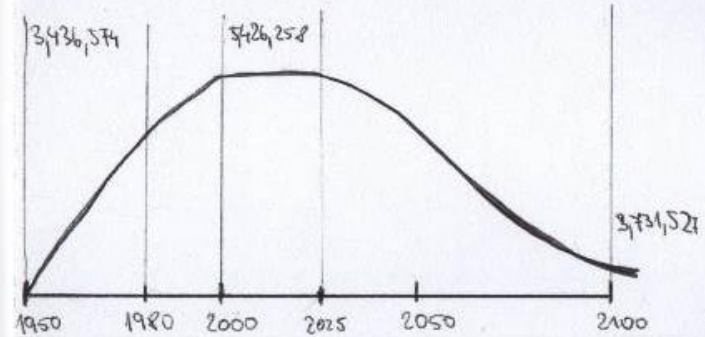

Od rokw 1950 marasd oby ratelor bol plymuli $\checkmark$ roluw 2000 mardala seagnáia poi dw obyrabutior, Plorá by mala truat do roke 2025. Po comblo rolue sa ocaliana miermy plyomily polles dyortel stra. Vrchol mastal os Selogini ait. pri poite olynatior sholo 5,5 miliomor

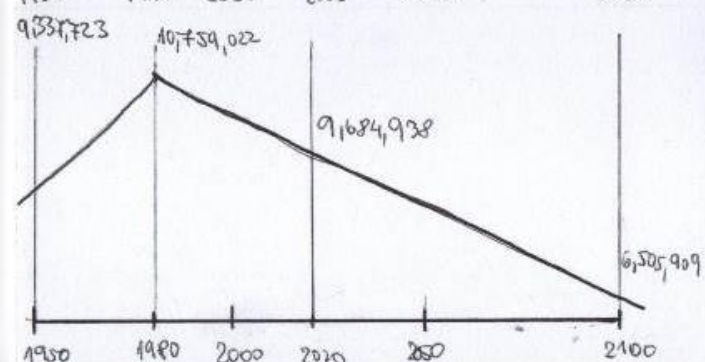

\section{MAD̆ARSKO}

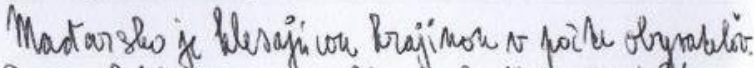
Sooj machol brajina dosi ablen ov vele 1980 . Od tolle voles sa kacial poict olyrabliou knizonad.

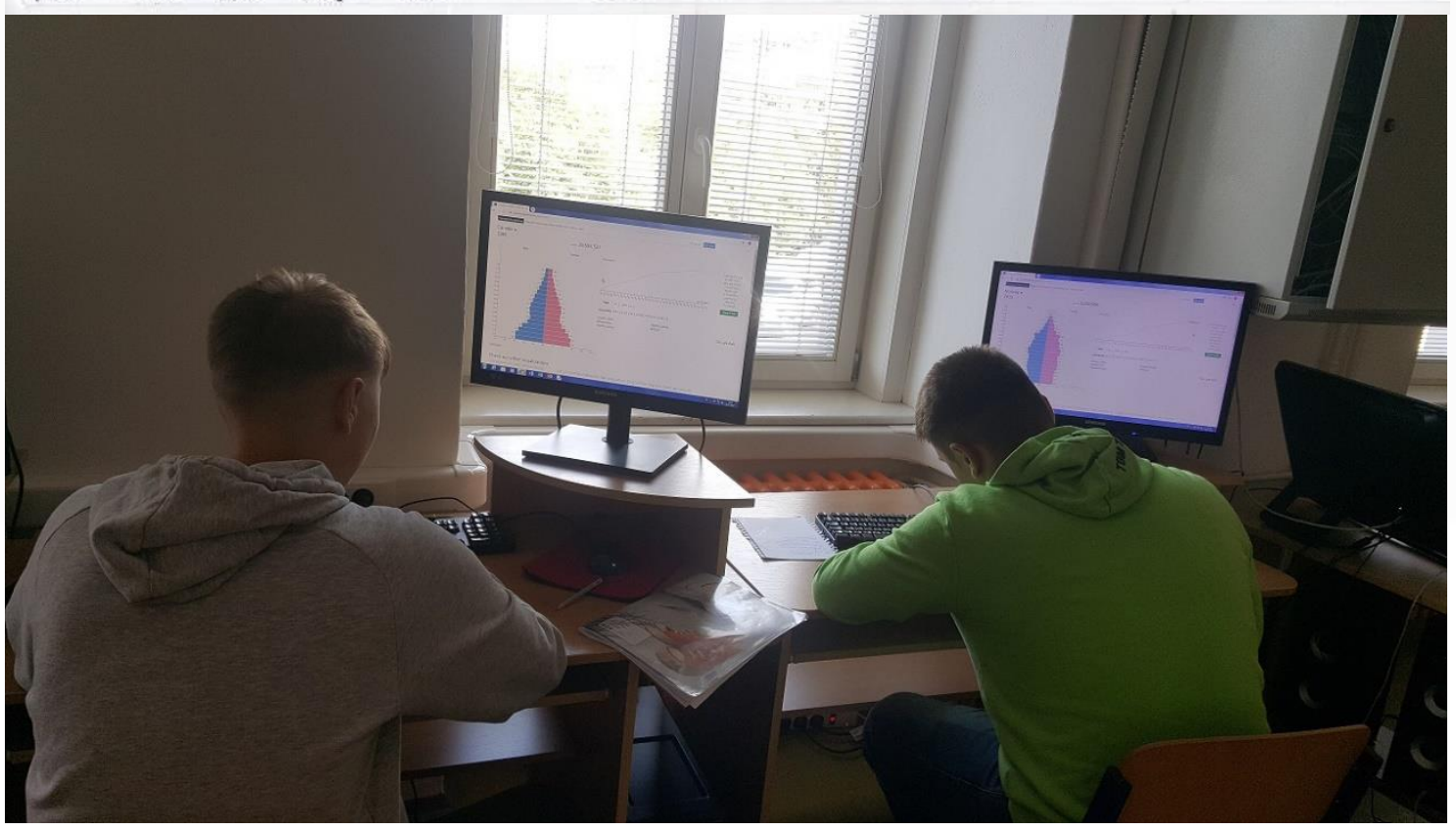

Figure 5. Students working on the activity Population prognosis

\section{Demographical Profiles of Selected States}

The final activity is devoted to the identification of factors that affect the number, development and distribution of the population within a state. In the past, areas with the highest population density were mainly determined by physical-geographical features-coasts, water bodies, fertile soil, mineral resources and others. At present, political, socio-economic and cultural factors 
can also significantly affect the dynamics of population, for example, a country where political decision caused fluctuations in the natural change of population such as the one-child policy in China or genocide in Cambodia. Culture, societal customs and traditions can also have a long-term impact on demographic phenomena, such as the aging population in Japan, or low rate of literacy in rural Tanzania. The activity is designed to help students understand that demographic dynamics have factual causes and consequences. This activity does not include the use of Web GIS tools.

\begin{tabular}{|c|c|}
\hline Acquiring knowledge & $\begin{array}{l}\text { Explain the factors (physical, socio-economic, } \\
\text { political or cultural) affecting the number, } \\
\text { development and distribution of world and national } \\
\text { populations } \\
\text { Distinguish between the causes and consequence of } \\
\text { population change } \\
\text { Explore population change determined by particular } \\
\text { situation in selected states }\end{array}$ \\
\hline Acquiring skills & Listening skills, critical analysis skills \\
\hline $\begin{array}{l}\text { Dominant cognitive } \\
\text { levels }\end{array}$ & $\begin{array}{l}\text { Understand } \\
\text { Analysis }\end{array}$ \\
\hline $\begin{array}{l}\text { Dominant modes of } \\
\text { spatial thinking }\end{array}$ & $\begin{array}{l}\text { Influence } \\
\text { Comparison } \\
\text { Change }\end{array}$ \\
\hline Cross-subject relations & History, Civics \\
\hline Approximate time & 45 minutes \\
\hline Assessment & $\begin{array}{l}\text { Using worksheet, students draw on their } \\
\text { understanding to reason the issues. }\end{array}$ \\
\hline
\end{tabular}

Students are asked to listen to the teacher speaking about selected aspects of population dynamics in five countries: China, Japan, Tanzania, United Arab Emirates and Cambodia. Students are then invited to complete the handout. Here, it is important for students to be able to explain the difference between cause and effect, for example "What caused the situation?" and "What did the situation result in?". Students should explain the differences between causes, consequences and measures occurring currently and in the past for the chosen states [Figure 6]: influx of cheap labor force; fast growing poor rural population; cultural habits and traditions; distinctive imbalance of genders, natality regulated by a state; oil and gas richness, education of illiterate population, oldest world population, young generation syndrome of celibate, dictatorship. Some students may demonstrate misunderstandings for some cases. 


\section{Demogeografické špecifiká vybraných štátov sveta}

prílev laenej pracovnej sily, rýchlo rastúce chudobné vidiecke obyvatelstvo, kultúrne zvyky a tradieie, výrazný nepomer pohtavi, štátom regulovaná pôrodnost', -bohatstvo z ropy, vzdelávanie negramotného obyvatel'stva, najstaršie-obyvatefstvo sveta; syndróm celibátu mladej generáeie, -dikłátorský fežim. *

\begin{tabular}{|c|c|c|c|}
\hline štát & príčina & následok & opatrenie \\
\hline Čína & $\begin{array}{l}\text { mycher nablice } \\
\text { chud sia objo }\end{array}$ & $\begin{array}{c}\text { viraxn' nepomer } \\
\text { rohlavi }\end{array}$ & Shílom negrelore \\
\hline Japonsko & $\begin{array}{l}\text { syndróm celibáde } \\
\text { mlady generacie }\end{array}$ & $\begin{array}{l}\text { najsearsie obyra- } \\
\text { uesero svela }\end{array}$ & $\begin{array}{l}\text { Milev lacnej } \\
\text { macooney sicy, wade }\end{array}$ \\
\hline Tanzánia & snyley a Mradicie & $\begin{array}{l}\text { xabtrianie albinot, } \\
\text { so\% abeinor sokdorige } \\
40 \text { rokor }\end{array}$ & $\begin{array}{l}\text { verini funkicie } \\
\text { pre albinov }\end{array}$ \\
\hline SAE & bohalskro 2 nopy & 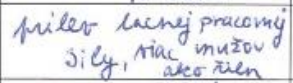 & \\
\hline Kambodža & $\begin{array}{l}\text { dilcialorsecy } \\
\text { revim }\end{array}$ & $\begin{array}{l}\text { yichlo raslice } \\
\text { chud. via. oby }{ }^{2} \text {. }\end{array}$ & \\
\hline
\end{tabular}

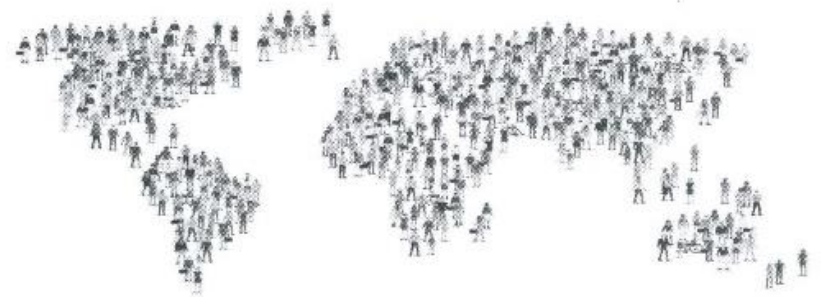

Figure 6. Student's product in the activity Demographical Profiles of Selected States

Teachers expressed overall satisfaction with the lesson:

It gave students new knowledge about world population of selected states in Africa and Asia. Teachers identified that students were able to use new terms (as expatriate or masculinity); and were stimulated to discuss the topic further. This activity induced discussion. Some teachers noticed their students were eager to look for further information about demographics of the countries after the lesson.

\section{Discussion}

The priority of the IT Academy project is to introduce inquiry-based lessons which are supported by the use of digital technologies to develop a more active process of acquiring geographical knowledge and skills. The value of the whole project on student achievement will be assessed in its final stage (Autumn 2020) by taking a scientific literacy test in June 2020. To find out the students' progression with science skills, all the participating subjects will be assessed jointly.

The expert team for Geography places emphasis on designing Geography lessons to be more inquiry-based, with real-life application and purposive use of Web GIS platforms. Such knowledge is marginally incorporated within the standards of the national curriculum and students can acquire technology and inquiry focused skills by primarily working with geographical information. The created model lessons for this project were piloted and evaluated by geography teachers in their schools across Slovakia. 
The paper presented examples of learning activities on the topic of World Political Map and World Population for secondary school students. Compared to prevailing instructional method transmission (Mesa10, 2019) the created activities are novel to the students and teachers. Students make use of a geographical inquiry method by exploring real-world issues at different scales. Students ask geographical questions, acquire geographical resources, collect and analyze data, discover relationships across time and space, and communicate their learning in presentations. The activities also assisted students in developing different modes of spatial thinking (dominantly comparison, influence and associations) and practicing both lower-order and higher-order cognitive thinking skills. Furthermore, student understanding about cross-subject relations with Geography become more thoroughly developed. The progression in student and teacher use of Web GIS platforms in learning activities is evolving.

The lower level of Web GIS integration is represented by student work with a website about geographical content, for example in State, Territory and Borders. Constructing age pyramid, for example, in; What does the age pyramid reveal? implies a middle level of Web GIS integration. Advanced integration is exemplified by the programming of creation a centroid, for example, in 'Find the ideal location of the capital city'. The learning objectives are assessed by formative assessment approaches, mainly by teachers analyzing, questioning, and discussing the oral and graphical work produced by their students and by discussing student satisfaction with the lesson.

Obviously, during the piloting process, the limitations of a traditional curriculum were identified, for example (i) the low number of geography lessons per week; (ii) teachers with weaker digital skills; and ultimately (iii) insufficient availability of digital technology equipment in schools. From teachers' subjective perceptions, it can be assumed such lessons enriched and enlivened the teaching and learning process and involved students more directly in their work. Teachers appreciated the prepared lessons plans and were able to suggest modifications for future delivery of such activities. Teachers also received positive feedback from students. Mostly students appreciated a new mode of instruction and upto-date of geographical issues.

\section{Conclusion}

Modern education should use modern technology to prepare students for the world of today and tomorrow. Computers and the Internet have contributed to significant change of the world and have affected teaching and learning of each single subject. According to the International Charter of Geographical Education (2016, p. 5) geography is a vital and stimulating subject which contributes to a lifelong enjoyment and understanding of our world. Geography contributes to education in that it uses powerful digital communication technologies such as GIS. Google maps, Google Earth and other geospatial technologies are entering into Geography classrooms (Hofierka, 2011; Solari et al., 2015). The purposeful joining of interesting geography topics, inquiry, and geospatial technologies have great potential to encourage constructivist geography education. The aim of this paper was to present the attempt at reconceptualizing and changing geography education in Slovakia using the frames of the IT Academy project by presenting a part of the outputs from the 
current study: a series of learning activities on World Political Map and World Population that involve geographical inquiry using different web GIS platforms. Findings from the study prove a geography curriculum should provide learners with opportunities to use geospatial technologies. The IT Academy project is one of a kind in Slovakia and has brought impetus to science, mathematics and informatics teaching. As a result, the outcomes of the networking partnerships between universities and secondary schools are looking promising for Geography, and for the time being, is considered to be successful with such innovations being welcomed by both teachers and students.

\section{Acknowledgment}

This paper was supported by the project KEGA 010UPJŠ-4/2020 "Geopriestorové technológie v bádatel'sky orientovanom vyučovaní geografie" [Geospatial technologies in inquiry-based geography teaching].

\section{References}

Artvinli, E. (2010). The contribution of Geographic Information Systems (GIS) to Geography Education and Secondary School Students' Attitudes Related to GIS. [Abstract] Educational Sciences: Theory and Practice, 10(3), 1277-1292. Retrieved from https://files.eric.ed.gov/fulltext/EJ919854.pdf

Čipková, E., Balážová, Z., \& Karolčík, Š. (2017). Rozvijanie prírodovednej gramotnosti žiakov gymnázia prostredníctvom bádatel'sky orientovaného Učenia. Biologie Chemie Zeměpis, 26(2), 2-10. Retrieved from http://bichez.pedf.cuni.cz/archive/2017/2/1.pdf

Csachová, S. (2018). Geografia na ceste ku koncepčnej inovácii v projekte IT Akadémia. Pedagogická revue, 65(3), 40-59. Retrieved from http://www.statpedu.sk/files/sk/ publikacna-cinnost/casopisy/pedagogicka-revue/2018/pedagogicka-revue-32018.pdf

Demirci, A. (2015). The effectiveness of geospatial practices in education. In Solari, O. M., Demirci, A., \& van der Schee J. (Eds.), Geospatial Technologies and Geography Education in a Changing World (pp. 141-154). Japan: Springer.

Gersmehl, P. (2014). Teaching Geography. (3rd ed.) New York: The Guilford Press.

Hofierka, J. (2011). Nové možnosti komunikácie geografickej informácie pomocou geopriestorovej internetovej technológie Google maps a Google Earth. Folia Geographica, 17(52), 100-108.

International Geographical Union. (2016). International Charter on Geography Education. Retrieved from https://www.igu-cge.org/2016-charter/

IT Akadémia - vzdelávanie pre 21. storočie, www.itakademia.sk

Karolčík, Š., \& Čipková, E. (2015). Využitie bádatel'sky orientovaných metód vo vyučovaní geografie. Geografická revue, 11 (1), 15-30.

Karolčík, ̌̌., Čipková, E., \& Mázorová, H. (2016). Application of digital technologies in the geography teaching process from the teachers' perspective, International Research in Geographical and Environmental Education, 25(4), 328-343. doi:10.1080/10382046.2016.1207992

Karolčík, Š., Likavský, P., \& Mázorová, H. (2015). Vývoj vyučovania geografie na základných školách a gymnáziách na Slovensku po roku 1989 a návrh základných koncepčných prvkov nového modelu geografického vzdelávania. Geografický časopis, 67(3), 261-284. 
Karvánková, P. (2015). Badatelsky orientované vyučování zeměpisu. Retrieved from http://test.sciencezoom.cz/documents/ke-stazeni/vystupy.pdf

Karvánková, P., Popjaková, D., Vančura, M., \& Nedvědová, Š. (2017). Inquiry-Based Education of Physical Geography. In Karvánková, P., Popjaková, D., Vančura, M., \& Mládek, H. (Eds.) Current Topics in Czech and Central European Geography Education (pp. 63-86). Switzerland: Springer. doi:10.1007/978-3-319-43614-2_5

Kerski, J. J. (2019a). Teaching Demography and Population Change Using Web GIS Tools and Data. The Geography Teacher, 16(3), 126-132. doi: $10.1080 / 19338341.2019 .1619608$

Kerski, J. J. (2019b). Teaching about Political Boundaries using WebGIS Tools and Data. The Geography Teacher, 16(4), 179-181. doi:10.1080/19338341.2019.1675080

Kireš, M., Šveda, D., Ješková, Z., Lukáč, S., Ganajová, M., Lešková, A., \& Csachová, S. (2019). Key innovation concepts of STEM education driven by IT Academy project. In: 17th IEEE International Conference on Emerging E-learning Technologies and Applications (pp. 378-382). Slovakia: Institute of Electrical and Electronics Engineers.

Král, L., \& Řezníčková, D. (2013). Rozšiření a implementace GIS ve výuce na gymnáziích v Česku. Geografie, 118(3), 265-283.

Mesa 10. 2019. Analýza zistení o stave školstva na Slovensku. To dá rozum. Retrieved from https://analyza.todarozum.sk

Milson, A. J., Demirci, A., \& Kerski, J., J. (2012). International Perspectives on Teaching and Learning with GIS in Secondary Schools. New York: Springer.

Mládek, J., Káčerová, M., Popjaková D., \& Vančura, M. (2017). Changes in Demographic Behaviour: Possible Use of Its Findings in Didactic Practice. In Karvánková, P., Popjaková, D., Vančura, M., \& Mládek J. (Eds.) Current Topics in Czech and Central European Geography Education (pp. 253-280). doi:10.1007/978-3-319-43614-2_14

National Institute for Education in Slovak Republic. (2015). State Educational Programme. Bratislava. Retrieved from http://www.statpedu.sk/sk/svp/inovovany-statnyvzdelavaci-program/

Orosová, R., Ganajová, M., Szarka, K., \& Babinčáková, M. (2019). Hodnotenie v prírodovedných predmetoch $\vee$ podmienkach slovenského školstva. Scientia in educatione, 10(1), 17-32.

Rehúš, M. (2018). Encyklopedizmus náš každodenný. Komentáre, 2, Bratislava: Inštitút vzdelávacej politiky, Ministerstvo školstva, vedy, výskumu a športu SR. Retrieved from https://www.minedu.sk/data/att/13792.pdf

Škodová, M., \& Schubertová, R., (2018). Výskumne ladený prístup v sprístupňovaní konceptov o vode krajine na základnej škole. In Čtrnáctová, H., Nesměrák, K., Teplá, M. (eds.) DidSci Plus - Research in Didactics Plus (pp. 383-392). Praha: Univerzita Karlova.

Škodová, M., \& Trniková, M. (2019). Príprava študentov na využívanie induktívneho prístupu vo vyučovaní geografie. In Vzdelávame pre budúcnost'. Zborník vedeckých a odborných štúdií (pp. 93-102). Banská Bystrica: Belianum.

Solari, O. M., Demirci, A., \& van der Schee, J. (Eds.) (2015). Geospatial Technologies and Geography Education in a Changing World. Geospatial Practices and Lessons Learned. Japan: Springer. doi:10.1007/978-4-431-55519_3

Tolmáči, L., \& Karolčík, Š. (2017). Current Geography Education in Slovakia: Conversions and Conditions. In Karvánková, P., Popjaková, D., Vančura, M., \& Mládek J. (Eds.) Current Topics in Czech and Central European Geography Education. doi:10.1007/978-3-319-43614-2_3 
Csachová, Stela. (2020) / Using webGIS platforms and inquiry-based activities to teach about ...

Van der Schee, J., Trimp, H., Béneker, T., \& Favier, T. (2015). Digital Geography Education in the Twenty-First Century: Needs and Opportunities. In Solari, O. M., Demirci, A., \& van der Schee J. (Eds.), Geospatial Technologies and Geography Education in a Changing World (pp. 11-20). Japan: Springer. doi:10.1007/978-4-431-55519_2

\section{Biographical statement}

Stela CSACHOVÁ is an assistant at the Institute of Geography, Faculty of Science, Pavol Jozef Šafárik University in Košice. She specifies on didactics of geography, the innovations in geography education with geospatial technologies in the scope of human- and regional-geographical topics. 